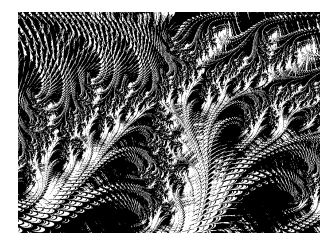

https://doi.org/10.5559/di.30.3.08

\title{
CONCEPTUAL FRAMEWORK FOR EXPLORATIONS OF THE COLLABORATIVE ECONOMY
}

Filip MAJETIĆ

Institute of Social Sciences Ivo Pilar, Zagreb, Croatia

UDK: 330.101 .8

330.131 .5

Review paper

Received: February 8, 2020

This paper aims to establish a comprehensive and easily operationalizable conceptual framework for explorations of the collaborative economy (CE). While the phenomenon has attracted increasing attention among businesses, customers, politicians/regulators, and researchers, a widely accepted conceptualization still does not exist. In the present study the CE accommodates for-profit and/or not-for-profit exchange of products that are: a) temporarily provided to others (i.e. shared) by their owners when the assets are under-utilized; b) shared occasionally i.e. up to a certain extent; c) shared by amateurs/ non-professionals when having a professional license is mandatory; and d) shared via on-line platforms. If all the requirements are (simultaneously) fulfilled, shared products embrace both goods and services and sharing providers embrace both individuals (e.g., P2P) and organizations (e.g., B2P). The proposed framework is discussed in the context of the CE key "surrounding" concepts - the on-demand economy, gig economy, second-hand \& circular economy, and rental economy.

Keywords: collaborative economy, conceptual framework, research field

Filip Majetić, Institute of Social Sciences Ivo Pilar, Marulićev trg 19/1, P.O. BOX 277, 10001, Zagreb, Croatia.

E-mail: Filip.Majetic@pilar.hr

\section{INTRODUCTION}

This paper aims to establish a comprehensive and - most importantly - easily operationalizable conceptual framework for (empirical) explorations of the collaborative economy (CE). 
DRUŠ. ISTRAŽ. ZAGREB GOD. 30 (2021), BR. 3, STR. 615-634

MAJETIĆ, F: CONCEPTUAL...
For the introductory i.e., orientational purpose, we begin with presenting a conceptualization of the CE that corresponds with the ones commonly used in academic, professional, and public discourse. Hence, the CE encompasses business models that meet all the following criteria simultaneously: "business transactions take place between three parties - the service provider, the online platform, and the customer"; "service providers offer access to their goods, services, or resources on a temporary basis"; "the goods, services or resources offered by the service provider are otherwise unused"; and "the goods, services, and resources are offered with or without compensation" (European Commission, 2016, 2018, p. 7).

Since the above-presented form of collaboration gets realized through sharing i.e. offering access to your own unused resources on a temporary basis, this business activity has been commonly labeled also as the sharing economy (e.g., Botsman, 2015; Ert et al., 2016; Frenken \& Schor, 2017; Leoni \& Parker, 2019). Although we also understand the collaborative and sharing economy as equivalent concepts and use the verb "sharing" extensively throughout the paper (because sharing enables collaboration in this context), to avoid terminological inconsistency the phenomenon will be labeled solely as the collaborative economy. ${ }^{1}$

The rationale for the study emerged from the two-fold setting. First, in terms of annual sales, number and variety of sellers, online platforms, and buyers, the global scene has been rapidly growing over the past decade and some of the actors (online platforms) have attracted substantial interest/funding from major venture capitalists (e.g., CapitalG, Sequoia Capital, and Goldman Sachs) (Schor, 2014). As an illustration, according to EU studies, 23\% of EU-28 respondents reported being CE users (product providers and/or buyers) in 2018 (European Commission, 2018a) and, in the same year, $19 \%$ of the respondents reported using on-line platforms to arrange accommodation from another person (Eurostat, 2019). Additionally, numerous aspects of the phenomenon have been heavily discussed among policy makers/regulators (e.g., impact on housing market, impact on traditional industries, precariousness of employment, tax avoidance) and the subject has been getting increasing attention from a wide range of researchers and experts (e.g., legal experts, economists, sociologists, marketing experts, opinion makers), whose main interests span CE conceptualizations (e.g., Frenken \& Schor, 2017; Ranjbari et al., 2018), typologies (Ertz et al., 2016; Perren \& Kozinets, 2018), social, environmental, and economic impacts on the CE (Porsch et al., 2018) as well as of the CE (Zervas et al., 2017; Katz, 2015; Martin et 
DRUŠ. ISTRAŽ. ZAGREB GOD. 30 (2021), BR. 3, STR. 615-634

MAJETIĆ, F: CONCEPTUAL... al., 2019), motives/drivers and socio-demographic characteristics of the actors (Barnes \& Mattsson, 2016), ownership and governance of on-line platforms (Leoni \& Parker, 2019), and online reputation and trust (Ert et al., 2016).

Second, despite all of it, from the researchers' and policy makers' point of view, i.e., from the exploration, regulation, and provision of public subsidies point of view, the CE field has been facing two fundamental obstacles. Namely, a widely accepted agreement about the exact content of the CE concept still does not exist. To put it more concretely, it often remains unclear exactly which business practices/operators can and cannot be labeled as a part of the CE (Dredge \& Gyimóthy, 2015; Murillo et al., 2017; Ranjbari et al., 2018). Inconsistent and often vague descriptions of the sharing have made the entire "project" prone to conceptual criticism (Arnould \& Rose, 2016) and misuse - e.g., in the case of "self-definition by the platforms" (Schor, 2014, p. 2). The other CE obstacle refers to many on-line platforms being "restrictive and selective in granting researchers access to their user data, citing privacy and competition concerns" (Frenken \& Schor, 2017, p. 8) resulting in "a significant body of 'grey' research that is generated by the protagonists of collaborative consumption" (Dredge \& Gyimóthy, 2015, p. 289). In other words, "there is little independent... (empirical) research on the topic" (Dredge \& Gyimóthy, 2015, p. 289; Muñoz \& Cohen, 2017). The present study addresses the more fundamental obstacle - the definitional one.

The paper is structured as follows. The background section contains an overview of the phenomenon emergence, main motivations for participants' engagement, and development/maintenance of intragroup trust and reciprocity. The research approach description is followed by the literature review, presentation of the conceptual framework, and discussion on basic differences between the CE and its key "surrounding" concepts: the on-demand economy, gig economy, second-hand \& circular economy, and rental economy (Frenken \& Schor, 2017). A brief recapitulation concludes the study.

\section{BACKGROUND OF THE STUDY}

Why has the collaborative economy become a (research) phenomenon? Taking into account that people all over the world have been collaborating through sharing their resources for decades (Belk, 2014), with or without remuneration, how come the activity had not made the core of a widespread business model until the late first decade of the 21st century ${ }^{2}$ (Schor \& Attwood-Charles, 2017)? What is the novelty nowa- 
DRUŠ. ISTRAŽ. ZAGREB GOD. 30 (2021), BR. 3, STR. 615-634

MAJETIĆ, F: CONCEPTUAL... ties and infrastructure that supports/enables it (Kovács et al., 2017). Namely, ICT enabled us to do the sharing with a wide(er) range of people (Kathan et al., 2016). During times before ICT we shared mainly among our acquaintances, friends, neighbors, relatives, and family - we shared with people we were familiar with and/or who operated in close proximity to us (Schor \& Fitzmaurice, 2015). Nowadays, ICT has enabled us to share with everyone who has access to the Internet (Kathan et al., 2016). This increase in the amount of (remunerated) sharing or collaborative transactions, accompanied by the corresponding increase in the number of online platforms, led to the phenomenon being labeled as "an economy".

Regardless of the technical infrastructure, why did people start sharing more extensively - with (complete) "strangers" (Schor, 2014) - approximately a decade ago? After all, the technology had been widely available years before the first examples of today's CE (Schor, 2014). It seems like the recent ("2008") global economic crisis was a powerful trigger. Lack of employment opportunities, indebtedness, difficult times for succeeding in entrepreneurship ventures, and reduced social transfers seemed to contribute to creation of a setting where sharing your own resources with "strangers" got recognized as a rational, favorable, and sustainable (business) behavior (Schor, 2014, 2017). Furthermore, in addition to sharing/collaborating for profit, a decade ago it also started making sense doing it with "strangers" for free (not-for-profit). For instance, either by having money completely excluded from transactions and benefiting from the reciprocity among actors (e.g., barter practices in the case of sharing household items on pumpipumpe.ch platform) or by receiving financial remuneration but only up to an extent of fully covering the service provision cost i.e. the cost of collaborating (e.g., transport providers in the case of BlaBlaCar company are not allowed to ask for money beyond breaking even) (Kathan et al., 2016). In other words, in addition to trying to make/save money (Botsman \& Rogers, 2010; Menor-Campos et al., 2019) and reduce the time needed to realize a business transaction (Schor, 2015), people participate in the CE also to fulfill some "higher-order needs" (Maslow, 1943) such as the need to contribute to environmental sustainability and overall economic stability, maintain good neighborliness, re-connect with society, feel a sense of community-belonging, gain new experiences, prioritize access (to goods) over ownership, and/or support the anti-materialism movement (Schor, 2014; Barnes \& Mattisson, 2016; Bucher et al., 2016; Alonso-Almeida et al., 2020). The last but not least background aspect, since in- 
DRUŠ. ISTRAŽ. ZAGREB GOD. 30 (2021), BR. 3, STR. 615-634

MAJETIĆ, F: CONCEPTUAL... tragroup activities on collaborative networks are governed horizontally (Ranjbari et al., 2018, p. 2336), the long-standing issue of establishing and maintaining trust in/among "strangers" (Schor, 2014) has been overcome - at least up to an extent which enables the business to keep going on - by introducing the rating systems, i.e. the mechanism where actors (customers and providers) build their on-line reputation through rating each other (Frenken \& Schor, 2017). Afterwards, trust among CE actors was additionally backed by "conventional" insurance companies entering the scene (e.g., according to Turo's official website, Allianz provides vehicle insurance for their fleet). These rating systems, i.e., transparent internal control systems have also been beneficial to nurturing the value of reciprocity. Namely, since reciprocity is vital, especially for the not-for-profit sharing, but at the same time a completely voluntary act, a convenient way to ensure that it spreads among intrinsically non-reciprocal participants (so-called "free-riders") has been through peer-pressure enabled by the rating systems (Proserpio et al., 2018; Hamari et al., 2016).

The CE conceptual framework was constructed and elaborated through three stages. First, the main aim of the literature review was to present inconsistencies in the field of previous conceptualizations. Second, grounded primarily in the content of these inconsistencies, the framework was sketched and clarified. Third, the discussion part discusses the framework in the context of previous research findings and the phenomenon's "surrounding" economies.

\section{LITERATURE REVIEW}

Starting from the introductory statement on the absence of definitional consensus, we broaden and deepen the definition-related research obstacle by introducing the wide-spread lack of scholarly interest (and/or need) to fully determine the CE's boundaries. In principle, apart from the key papers in the field that dealt specifically with the conceptualization issues (Schor, 2014; Dredge \& Gyimóthy, 2015; Martin, 2016; Frenken \& Schor, 2017; Muñoz \& Cohen; 2017; Murillo et al., 2017; Ranjbari et al., 2018; Ertz et al., 2019), this lack has been present in the majority of CE studies. While the final outcome remains the same, the issue varies from: a) CE studies offering no definitional framework at all, i.e. considering the concept self-explanatory (Ranjbari et al., 2018), b) studies describing the phenomenon vaguely, i.e. often only by mentioning a few examples such as Airbnb and Uber in the introduction (Ranjbari et al., 2018), c) studies overcoming/dodging the need to define the phenomenon by acknowledging (in the 
DRUŠ. ISTRAŽ. ZAGREB GOD. 30 (2021), BR. 3, STR. 615-634

MAJETIĆ, F: CONCEPTUAL... introduction) its multidimensionality and complexity as well as the absence of definitional consensus (e.g., Del Moral-Espin \& Fernandez-Garcia, 2018), and d) studies thoroughly discussing only a reduced set of CE characteristics - most commonly (e.g., Hamari et al., 2016) the one relevant for the subject of their interest (Ranjbari et al., 2018).

Building on the key papers in the field and in the last category (d), we turn to presenting the main inconsistencies among previous attempts to deliver a coherent CE definitional framework. The presentation is organized within seven most debatable topics regardless of the name used to label the phenomenon and regardless of the discipline-based perspective taken.

The first topic refers to online vs. offline transactions. For instance, Belk (2014, p. 1599) states that CE companies were founded on ICT or "disruptive technologies", while Hamari et al. (2016, p. 2047) call it an "economic-technological phenomenon". Moreover, due to the role of ICT in enabling the CE, discussing any aspect of the phenomenon predominantly through the lens of online platforms seems to be a common research approach (e.g., Kathan et al., 2016). On the other hand, e.g., Ertz et al. (2016) do not employ this technological determinism but fit both online and offline transactions under the CE umbrella.

Second, temporary vs. permanent access to shared products. For Perren and Kozinets (2018) and Hamari et al. (2016, p. 2053), the CE encompasses the following modes of exchange: "sharing, swapping, bartering, trading or renting access". Similarly, according to Ertz et al. (2016, p. 198), the CE "... enables consumers to both obtain and provide, temporarily or permanently, valuable resources or services...". However, for the majority of CE researchers, precisely the temporariness of access makes an unavoidable CE feature, a feature that distinguishes it from non-sharing exchanges such as trading and bartering where the recipient becomes the new owner of traded/bartered products (Ranjbari et al., 2018).

Third, length and/or frequency of providing temporary access. Porsch et al. (2018) restricted the frequency of providing temporary access suggesting that the CE supports only occasional provisions. Following the same line of thinking, e.g., Belk (2014, p. 11) emphasizes that long-term renting or leasing makes a "pseudo-sharing" practice, i.e. it represents "a business relationship masquerading as communal sharing". On the other hand, e.g., Hawlitschek et al.'s (2016) "peer-to-peer rental" concept does not mention the frequency criterion which, consequently, equalizes activities of sharing and renting. The latter group commonly approaches the phenomenon from the consumer's perspective discussing the CE fea- 
DRUŠ. ISTRAŽ. ZAGREB GOD. 30 (2021), BR. 3, STR. 615-634

MAJETIĆ, F: CONCEPTUAL... tures (primarily) within the trend of neo-consumerism where access is favored over ownership, i.e. within the trend of "access-based consumption" (Bardhi \& Eckhardt, 2012). Using Arvidsson's words (2018, p. 289), this approach "denotes (collaborative) consumption rather than production".

Fourth, the economic sustainability category contains the dichotomy of for-profit (profit-driven) vs. not-for-profit (social mission-driven) exchanges and the dichotomy of monetary vs. non-monetary contribution. Most of the scholars (e.g. Codagnone et al., 2016; Ertz et al., 2016) included in the CE both for-profit and not-for-profit sharing. The "true" CE transactions being solely not-for-profit seem to have stopped being a valid option in the post Uber and Airbnb period (from c. 2008 onwards) (Belk, 2014a; see also: Ranjbari et al., 2018). In terms of currencies used, e.g., Benoit et al. (2017, p. 2) included solely sharing with "monetary contribution" unlike e.g., Del Moral-Espin and Pais (2015), who made no such restrictions by adding provision of services within the "hour-per-hour" instead of the "money-per-hour" scheme, i.e. digital time banking. Anyhow, regardless of the means, according to Muñoz and Cohen's (2017) all-inclusive typology of CE business models ("Crowd-based tech", "Collaborative consumption", "Business to crowd", "Spaced-based, low-tech sharing", and "Sharing outlier"), sustainability represents a must in all of them - as it is the case in any other economy.

The fifth category refers to the type of product providers - individuals vs. organizations and professionals (professionally licensed product providers) vs. amateurs. For instance, Demary and Engels (2016) and Benoit et al. (2017) claim that only peer service makes the CE. Vaughan and Daverio's (2016) definition comprises both individuals (P2P/B) and companies (B2P/B). Codagnone et al. (2016, p. 22) proposed the most inclusive conceptualization which includes all "interaction modalities" - "P2P, P2B, B2P, B2B, and G2G". Regarding the (eligibility of) amateurs vs. professional license holders, the EC study (2018) excluded cases where legal engagement in certain activity requires providers to be professionally licensed. The other EC study (2018a, p. 2) offered a slightly different view: "(in the CE) ... citizens and entrepreneurs offer services either on an occasional basis or professionally". In other words, both professionals and amateurs are eligible participants. Perren and Kozinetz (2018, p. 19) even saw the two groups as equals in participation on online platforms: "even though some of the actors in a given network might be professionals, whereas others might be amateurs, their participation through the exchange platform renders the two groups roughly equivalent". 
DRUŠ. ISTRAŽ. ZAGREB GOD. 30 (2021), BR. 3, STR. 615-634

MAJETIĆ, F: CONCEPTUAL...
Sixth, the nature of shared products: goods vs. services. For instance, Codagnone et al.'s (2016, p. 22) inclusive definition encompasses sharing of "... capital assets (money, real estate property, equipment, cars, etc.) goods, skills, or just time". On the other hand, according to e.g., Frenken and Schor (2017), only goods get to be shared within the CE. A less disputable aspect of this category claims the CE has "commercialized aspects of life previously beyond the reach of the market" (Martin, 2016, p. 149); it has introduced to the market products that "in themselves (are) not directly susceptible to market exchange" (Arvidsson, 2018, p. 289). The disagreement here might again begin with the scope of commercialization. According to Frenken and Schor (2017, p. 5), a majority of these newly commercialized, personal items such as "...clothing, computers and furniture" do have the capacity to be under-utilized, which means they are shareable, but some items such as "eyeglasses" and "mobile phones" do not have this capacity, which makes them non-shareable. However, the criteria they used for under-utilization capacity assessment can hardly be generalized - there seems to be no substantial difference between the shareability level of clothing vs. eyeglasses (in terms of e.g., protecting personal hygiene standards) and between mobile phones and computers (e.g., in terms of protecting sensitive personal data).

The seventh topic, sharing gets realized through intermediaries vs. receivers have direct access to providers. In the Ertz et al. (2016, p. 198) and Menor-Campos et al.'s (2019) view "... resources or services (get shared) through direct interaction with other consumers or through an intermediate". According to many others, a distinctive feature of the CE is consumers being served not directly by product providers ("auto-mediated P2P exchanges") but exclusively through intermediaries, i.e., online platforms ("market-mediated access") (Bardhi \& Eckhardt, 2012; Dredge \& Gyimóthy, 2015; Ranjbari et al., 2018).

The discussed topics represent fundamental pillars of the CE conceptualization (see also Ranjbari et al., 2018), and, up to a certain extent, all of them have obviously been open questions. Therefore, building primarily on these questions, the section below makes an additional attempt to sketch a comprehensive conceptual framework.

\section{CONCEPTUAL FRAMEWORK}

What gets to be shared within the collaborative economy and who participates in the collaboration?

The CE accommodates for-profit and/or not-for-profit exchange of products:

a) that are temporarily provided to others (i.e., shared) by their owners when the assets are under-utilized (e.g., Fren- 
DRUŠ. ISTRAŽ. ZAGREB GOD. 30 (2021), BR. 3, STR. 615-634

MAJETIĆ, F: CONCEPTUAL... b) that are shared occasionally i.e., up to a certain extent (e.g., Porsch et al., 2018);

c) that are shared by amateurs/non-professionals when having a professional license is mandatory (e.g., European Commission, 2018); and

d) that are shared via on-line platforms (e.g., Hamari et al., 2016).

As an illustration, a hypothetical CE provider might be a clerk who provides strangers with temporary access to their underutilized drilling machine. The access is offered for a fee, sporadically i.e., only if/when the owner faces a major unexpected expense, and the transaction gets realized through pumpipumpe.ch - an online platform for household items sharing.

Several clarifications are required at this point:

First, this conceptualization is focused neither on the recipients (consumption) nor the online platforms (logistics), but on the product providers (production) i.e., it aims to determine what type of product providers - sellers - make the CE. Platforms are understood merely as intermediaries which could host, among others, a certain share of CE providers. Based on the share of CE providers hosted, platforms could be labeled as contributors to the CE (European Commission, 2018; see also Ranjbari et al., 2018). Type of consumers/recipients makes no difference in defining this economy - eligible participants are both consumers and prosumers, barter and time-banking fans, profit-driven and social mission-driven actors, etc. Their ratios might affect the sustainability of the CE but not its basic settings.

Second, our standpoint implies that shared assets must be legally owned by the provider (Belk, 2014) and returnable to the owner. This excludes e.g., sharing of illegal files (copyrighted materials) because they are neither legally owned by the provider nor returnable to them.

Third, it also implies that shared products have been acquired for personal use in the first place because it would not make (business) sense to acquire for the purpose of trading something that cannot be traded frequently/extensively. In the case of shared goods, this corresponds to Arvidsson's (2018, p. 289) exchange of goods that are "not directly susceptible to market exchange".

Fourth, the existence of CE fundamentally relies on a high number of providers - not just a high number of business transactions - because a single provider's number of transactions is limited.

Fifth, in the context of the offline vs. online discussion as well as the direct access vs. intermediary discussion, being a part of the "platform" or "digitally based new economy" (Ken- 
DRUŠ. ISTRAŽ. ZAGREB GOD. 30 (2021), BR. 3, STR. 615-634

MAJETIĆ, F: CONCEPTÜAL...

\section{DISCUSSION}

ney \& Zysman, 2016) and the transactions being conducted via online intermediaries is crucial for the CE because this way it is possible to accommodate a large volume of participants more efficiently - this is a necessity in an economy that, as it was just mentioned, allows only occasional provision of idle resources i.e., relies on a high number of providers.

Sixth, since the for-profit and not-for-profit as well as the monetary and non-monetary options are all valid in this framework, the sustainability of the platforms often cannot rely on charging a percentage of revenue but (also) on membership fees, alternative external funding (e.g., the state supporting social mission-driven platforms) (Muñoz \& Cohen, 2017), and on-site advertising (Kenney \& Zysman, 2016).

Seventh, if all the requirements are met (a), b), c), d)), the $\mathrm{CE}$ embraces exchange of both goods and services (in line with Codagnone et al.'s inclusive (2016) definition) and the group of product providers consists of both individuals and organizations (in line with the inclusive Vaughan and Daverio (2016) as well as Codagnone et al.'s (2016) definition). However, due to the necessity to simultaneously fulfill all the requirements, the majority of shared products will most likely fall under the umbrella of goods instead of services and will most likely be provided by individuals instead of organizations. Namely, in terms of goods vs. services, it just seems hard to expect having a substantial amount of e.g., haircutting or gardening services offered on occasional basis by amateurs. In terms of who gets to share within the CE, it seems equally hard to expect having a substantial amount of e.g., companies occasionally renting out their fleet vehicles. ${ }^{3}$

The following section discusses the framework in the context of previous research findings and, to further elaborate its standpoint and illustrate that a distinct concept has been created, draws tangible lines between product providers in the collaborative economy and those in the "surrounding (platform) economies": the on-demand economy, gig economy, second-hand \& circular economy, and rental economy (Frenken \& Schor, 2017). Namely, these "surrounding" concepts put emphasis on elements different than the CE but have (frequently) been reported as significantly overlapping with it ${ }^{4}$ (Dredge \& Gyimóthy, 2015; Frenken \& Schor, 2017; Martin, 2016). Moreover, researchers and writers (including the press) are not the only group that misplaces the "surrounding" concepts in the context of collaborative economy. Companies (online platforms) coming from the surrounding fields also tend to do so - often deliberately - by trying (investing time and 
DRUŠ. ISTRAŽ. ZAGREB GOD. 30 (2021), BR. 3, STR. 615-634

MAJETIĆ, F: CONCEPTUAL... money) to be perceived as an integral part of the CE scene because being there provides them with clear business benefits such as growth of loyal customer base (Kalamar, 2013; Slee, 2015). Kalamar (2013) summed it up nicely, "sharewashing is the new greenwashing" implying that the ongoing hype around being (perceived as) "sharing/collaboration-friendly" equals the long-lasting hype around being (perceived as) "green-friendly". Following the same logic, the "greenwashing" could easily be substituted with "social entrepreneurship-washing" (see Floyd, 2012). In any case, presenting themselves as successful in internalizing various types of "social-connectedness" (Frenken \& Schor, 2017, p. 4) seems to be an important goal for businesses nowadays.

Hence, the on-demand economy encompasses business transactions that get realized "instantly" i.e., shortly after a demand is being expressed; these transactions have been present on the market for decades and nowadays are usually conducted via on-line platforms which makes the economy more efficient than ever before (Kerrigan, 2018). Customers ask for a ride (e.g., Uber), meals (e.g., UberEats), accommodation (e.g., Booking.com), or vintage accessories (e.g., Etsy) and get it shortly after the order has been placed. In the context of our framework i.e., CE requirements, borrowing your money up to a certain extent to strangers through LendingClub platform - e.g., occasional micro-financing for a fee - makes you a collaborative economy actor, while doing it frequently and/ or on a large scale makes you an on-line investor (see Frenken \& Schor, 2017). Using the same logic but introducing also the "amateurism" requirement (c), a professional/licensed driver who occasionally operates through online platforms such as Uber is an occasional taxi driver i.e., an on-demand, not collaborative economy actor (Frenken \& Schor, 2017; Botsman, 2015). On the other hand, following Porsch et al. (2018), Belk (2014), and European Commission's (2018) line of reasoning, if the regulatory framework allows on-demand car rides to be provided by an amateur/unlicensed driver (usually it does not) and that amateur does them occasionally, the service was provided by a collaborative economy actor - regardless of the type of on-line platform the rides were ordered through. However, within the ride sharing sphere, there is a crucial difference between two types of providers. The first ones let others (passengers) decide about the route and drive them to their destination point - which essentially represents the ride-hailing option (the hypothetical case of occasional Uber or Lyft amateur drivers) (Meelen \& Frenken, 2015). The second ones invite people to join them on their preselected route which reduces the transportation costs (the case of BlaBlaCar) (Meelen 
DRUŠ. ISTRAŽ. ZAGREB GOD. 30 (2021), BR. 3, STR. 615-634

MAJETIĆ, F: CONCEPTUAL...
\& Frenken, 2015). A brief digression related to the BlaBlaCar and similar business models has to be made here - a violation of the "frequency" requirement (b) should be tolerated if a person commutes daily to work by car (between two cities) and frequently provides (different) strangers with access to an empty car seat on that ride - this can be considered a form of the "pure" sharing/collaboration and, consequently, a part of the CE. The same logic will be applied afterwards in the case of frequently renting out a room in the apartment you live in.

The gig economy embraces workers, often-called "independent contractors", who do (usually short-duration) freelance jobs for living - it represents the opposite of an economy that embraces workers with stable (full-time or part-time) employment (Friedman, 2014, p. 171). For instance, a gig economy worker is an architect who makes their living by doing short-term (architecture-related) projects through Upwork platform or a dog walker who makes their living through Wag! platform (Schor, 2017). Two fundamental differences between this architect gig worker and CE workers, again following Porsch et al. (2018), Belk (2014), and European Commission's (2018) line of reasoning, are the professionalism and frequency of service provision - the architect is a licensed professional who makes their living by frequently providing the same type of service. In the case of Wag! dog walker, a fundamental difference is not the professionalism, because most likely a professional license to do the job is not needed, but the frequency of service provision remains a key difference. The collaborative economy, as already stated, is composed of numerous both occasional and amateur product providers.

Furthermore, the activity of selling used usable personal items through Amazon, eBay, or Etsy falls (apart from within the on-demand economy) within the second-hand economy which accommodates activities of giving/acquiring permanent access over used items (Frenken \& Schor, 2017). When it comes to unusable (personal) items (e.g., worn-out clothes, broken electronics), donating/selling them to a recycling or remanufacturing company makes someone a contributor to circular i.e., zero-waste, recycling, and reusing economy - not the collaborative economy (Kircherr et al., 2017). Selling/donating used personal items cannot be labeled a part of the CE because it goes beyond providing temporary access to them ${ }^{5}$ (Frenken \& Schor, 2017).

Regarding the differences between the collaborative and rental economy, as an initial illustration, continuously/frequently renting out your apartment makes you a part of the rental economy, not the CE which supports provision of occasional, short-term access to your property - for instance, through 
DRUŠ. ISTRAŽ. ZAGREB GOD. 30 (2021), BR. 3, STR. 615-634

MAJETIĆ, F: CONCEPTUAL...
Airbnb at times you are on holidays (Meelen \& Frenken, 2015; Frenken \& Schor, 2017). The same reasoning applies in the case of the car sharing industry organized around the idea of letting other people use your own car during times you do not need it (Kathan et al., 2016). Predominantly, it is a P2P business (e.g., Turo, Getaround, Drivy). On the other hand, rental companies often associated with the collaborative economy have acquired a fleet of vehicles for the purpose of continuously renting them out (see Zipcar, nowadays a part of Avis Budget Group) (Schor, 2015). Hence, regardless of the fact that companies of this type do business in a flexible, innovative, and convenient way, i.e. offer options to drive by the minute, hour, or day; allow you to park a borrowed car wherever it suits you after the ride is completed; offer on-line reservations; do not require customers to refill the tank, etc. they still represent the rental (and on-demand) economy (Schor, 2014). There are numerous official (state-supported) ways to establish clear distinctions in the field differences between the sharing/collaborating and renting. For instance, it might be number of days invested in the sharing i.e., the frequency of sharing (the rental economy starts above a certain number of days per year, and in the case of e.g. home sharing, differences between primary and non-primary residences are also taken into account) (Porsch et al., 2018). In the case of Airbnb in e.g., France, according to their official guidelines for shortterm accommodation providers, the $\mathrm{CE}$ embraces sharing primary residences in full for up to 120 days per year. Single rooms in primary residences can be shared without any limitations - based on the previously described "pure sharing" exemption. On the other hand, renting secondary residences is not at all considered a part of the $\mathrm{CE}$, but the rental economy, which means they can be shared without any limitations as long as the rental activity is declared and approved by the local authorities. The approval is often based on the zoning regulations preventing the entire residential areas being converted to non-residential, tourist ones. Furthermore, the criterion might also be the number of units a single person lists through an online platform (the rental economy starts above a certain number of listings per person) (Schor, 2014). According to Slee (2015), 93\% of all Airbnb transactions in New York City were made by $13 \%$ of the hosts and these $13 \%$ listed more than one property. In other words, $93 \%$ of the NYC Airbnb transactions were probably not made by the CE but the rental economy actors. Finally, the distinction might be made based on the amount of money made from the sharing transactions (the rental economy starts above a certain amount), which is usually positively correlated with both the frequency of sharing and number of units shared. 
In attempting to make the collaborative economy framings less "contrasting and contradictory" (Martin, 2016, p. 149) and complement similar previous efforts (Frenken \& Schor, 2017; Murillo et al., 2017; Ranjbari et al., 2018), we propose a conceptual framework which encompasses actors involved in for-profit and/or not-for-profit exchange of products that are: a) temporarily provided to others (i.e. shared) by their owners when the assets are under-utilized (Frenken \& Schor, 2017); b) that are shared occasionally i.e. up to a certain extent (Porsch et al., $2018)$; c) that are shared by non-professionals in cases a professional license is required (European Commission, 2018); and d) that are shared via on-line platforms (Hamari et al., 2016). If all the requirements are (simultaneously) fulfilled, shared products embrace both goods and services and sharing providers embrace both individuals (e.g., P2P) and organizations (e.g., B2P). Regarding the main differences between the CE and the four "surrounding" concepts, the following can be concluded. Although all of them do represent a part of the "digitally based" economy (Kenney \& Zysman, 2016), second-hand \& circular economy actors provide permanent access to their resources, unlike collaborative economy actors who do it on a temporary basis. Furthermore, unlike collaborative economy actors who are non-professionals and share their under-utilized resources occasionally, on-demand, gig, and rental economy actors trade their resources frequently i.e., whenever possible/ profitable and, where needed, have their business activities institutionalized through holding required professional certifications. Apart from the independent research community, this conceptualization could be a starting point also for scholars advising politicians on supporting CE businesses (e.g., partial tax exemptions), CE professional/networking projects, and on regulating the scene. Namely, while certain tangible improvements have been made in the field of CE vs. rental economy, much work on distinguishing the CE from gig and on-demand economy seems to be ahead of the regulators - at the level of implementing both regulations and effective controls. The main limitation of our conceptualization emerges from its reduced ability to accommodate organizations, in particular businesses, as CE providers. This might motivate future studies to aim at proposing more flexible definitional frameworks - without overextending the boundaries of the CE concept.

\section{NOTES}

${ }^{1}$ The collaborative consumption (Belk, 2014a) is another concept that we, as well as some other researchers (e.g., Benoit et al., 2017), understand to be synonymous with the collaborative economy.

${ }^{2}$ Schor and Attwood-Charles $(2017$, p. 2) stated that "what is now known as the sharing economy is typically dated to 2008 , with the 
DRUŠ. ISTRAŽ. ZAGREB GOD. 30 (2021), BR. 3, STR. 615-634

MAJETIĆ, F: CONCEPTÜAL...

founding of Airbnb and Uber". One of the predecessors might be HomeExchange (home and apartment exchanges) which transferred its activities on-line in 1995 (Mordowanec, 2017).

This paper does not include ideas of e.g., Benkler (2004) and Lessig (2008) - i.e., papers that were either prepared or published before the Airbnb and Uber time. Namely, although they have often been mentioned as the pioneers of scholarly work on the collaborative consumption and collaborative/sharing economy (Dredge \& Gyimóthy, 2015), the phenomena they were addressing differ from what this study recognizes as the collaborative economy and "what is now known" as the collaborative economy (Schor \& Attwood-Charles, 2017); it differs context-wise and/or content-wise. For instance, from today's point of view it has become obsolete to discuss non-remunerated sharing as the only form of "true" sharing (Belk, 2014a).

${ }^{3}$ Taking into account that national regulatory frameworks usually require legal persons to be formally registered for all the business activities they perform, we do not necessarily equalize this registration with professional licenses. Namely, following requirement c), equalization would instantly exclude legal persons from the CE.

${ }^{4}$ These are not the only "overlapping" concepts. For instance, Kenney \& Zysman (2016) labeled the CE as synonymous with "platform economy". Although we do find this conclusion inaccurate, the platform economy was excluded from our analysis because, in this definitional context, it lacks distinctive content. Namely, we understand the platform economy as (merely) an umbrella term for all ICT enabled economies - including the $\mathrm{CE}$ and online versions of its surrounding economies.

${ }^{5}$ The gift economy (Eisenstein, 2011) represents another concept often associated with the $\mathrm{CE}$ where access to resources is given on permanent (instead of temporary) basis.

\section{REFERENCES}

Alonso-Almeida, M., Perramon, J., \& Bagur-Femenías, L. (2020). Shedding light on sharing economy and new materialist consumption: An empirical approach. Journal of Retailing and Consumer Services, 52, 101900. https://doi.org/10.1016/j.jretconser.2019.101900

Arnould, E. J., \& Rose, A. S. (2016). Mutuality: Critique and substitute for Belk's 'sharing'. Marketing Theory, 16(1), 75-99. https://doi.org/10. 1177/1470593115572669

Arvidsson, A. (2018). Value and virtue in the sharing economy. The Sociological Review Monographs, 66(2), 289-301. https://doi.org/10.1177/ 0038026118758531

Bardhi, F., \& Eckhardt, G. M. (2012). Access-based consumption: The case of car sharing. Journal of Consumer Research, 39(4), 881-898. https://doi. org/10.1086/666376

Barnes, S. J., \& Mattsson, J. (2016). Understanding current and future issues in collaborative consumption: A four-stage Delphi study. Technological Forecasting and Social Change, 104, 200-211. https://doi.org/ 10.1016/j.techfore.2016.01.006 
DRUŠ. ISTRAŽ. ZAGREB GOD. 30 (2021), BR. 3, STR. 615-634

MAJETIĆ, F: CONCEPTUAL...
Belk, R. (2014). You are what you can access: Sharing and collaborative consumption online. Journal of Business Research, 67, 1595-1600. https://doi.org/10.1016/j.jbusres.2013.10.001

Belk, R. (2014a). Sharing versus pseudo-sharing in Web 2.0. Anthropologist, 18(1), 7-23. https://doi.org/10.1080/09720073.2014.11891518

Benkler, Y. (2004). Sharing nicely: On shareable goods and the emergence of sharing as a modality of economic production. The Yale Law Journal, 114(2), 273-358. https://doi.org/10.2307/4135731

Benoit, S., Baker, T. L., Bolton, R. N., Gruber, T., \& Kandampully, J. (2017). A triadic framework for collaborative consumption (CC): Motives, activities and resources \& capabilities of actors. Journal of Business Research, 79, 219-227. https://doi.org/10.1016/j.jbusres.2017.05.004

Botsman, R. (2015 May 27). Defining the sharing economy: What is collaborative consumption - and what isn't? Fast Company. https://www. fastcompany.com/3046119/defining-the-sharing-economy-what-iscollaborative-consumption-and-what-isnt

Botsman, R., \& Rogers, R. (2010). What's mine is yours: The rise of collaborative consumption. Harper.

Bucher, E., Fieseler, C., \& Lutz, C. (2016). What's mine is yours (for a nominal fee): Exploring the spectrum of utilitarian to altruistic motives for internet-mediated sharing. Computers in Human Behavior, 62, 316-326. https://doi.org/10.1016/j.chb.2016.04.002

Codagnone, C., Biagi, F., \& Abadie, F. (2016). The Passions and the interests: Unpacking the sharing economy. Institute for Prospective Technological Studies, JRC Science for Policy Report EUR 27914 EN. https:// doi.org/10.2139/ssrn.2793901

Del Moral, L., \& Pais, I. (2015). Collaborative economy and the digitalization of timebanking: Opportunities and challenges. Studi di Sociologia, 1, 3-21.

Del Moral-Espin, L., \& Fernandez-Garcia, M. (2018). Moving beyond dichotomies? The collaborative economy scene in Andalusia and the role of public actors in shaping it. The Sociological Review Monographs, 66(2), 401-424. https://doi.org/10.1177/0038026118758539

Demary, V., \& Engels, B. (2016). Collaborative business models and efficiency. Potential efficiency gains in the European Union. Cologne Institute for Economic Research.

Dredge, D., \& Gyimóthy, S. (2015). The collaborative economy and tourism: Critical perspectives, questionable claims and silenced voices. Tourism Recreation Research, 40(3), 286-302. https://doi.org/10.1080/02 508281.2015.1086076

Eisenstein, C. (2011). Sacred economics: Money, gift, and society in the age of transition. North Atlantic Books.

Ert, E., Fleischer, A., \& Magen, N. (2016). Trust and reputation in the sharing economy: The role of personal photos in Airbnb. Tourism Management, 55, 62-73. https://doi.org/10.1016/j.tourman.2016.01.013

Ertz, M., Durif, F., \& Arcand, M. (2016). Collaborative consumption or the rise of the two-sided consumer. International Journal of Business and Management, 4(6), 195-209. 
DRUŠ. ISTRAŽ. ZAGREB GOD. 30 (2021), BR. 3, STR. 615-634

MAJETIĆ, F: CONCEPTÜAL...
Ertz, M., Durif, F., \& Arcand, M. (2019). A conceptual perspective on collaborative consumption. Academy of Marketing Science Review, 9, 27-41. https://doi.org/10.1007/s13162-018-0121-3

European Commission (2016). Communication from the Commission to the European Parliament, the Council, the European Economic and Social Committee and the Committee of the Regions. A European agenda for the collaborative economy. Publications Office of the European Union.

European Commission. (2018). Study to Monitor the Economic Development of the Collaborative Economy in the EU - Final Report. Publications Office of the European Union.

European Commission (2018a). Flash Eurobarometer 467. The use of the collaborative economy. Brussels, Belgium.

Eurostat (2019). Are you part of the collaborative economy? https:/ec.europa. eu/eurostat/web/products-eurostat-news/-/DDN-20190416-1

Floyd, D. (2012, December 11). Mythbusting: Bogus firms threaten social enterprise movement. The Guardian. https://www.theguardian.com/socialenterprise-network/2012/dec/11/mythbusting-bogus-social-enterprisethreat

Frenken, K., \& Schor, J. (2017). Putting the sharing economy into perspective. Environmental Innovation and Societal Transitions, 23, 3-10. https://doi.org/10.1016/j.eist.2017.01.003

Friedman, G. (2014). Workers without employers: Shadow corporations and the rise of the gig economy. Review of Keynesian Economics, 2(2), 171-188. https://doi.org/10.4337/roke.2014.02.03

Hamari, J., Sjöklint, M., \& Ukkonen, A. (2016). The sharing economy: Why people participate in collaborative consumption. Journal of the Association for Information Science and Technology, 67(9), 2047-2059. https:// doi.org/10.1002/asi.23552

Hawlitschek, F., Teubner, T., \& Gimpel, H. (2016). Understanding the sharing economy-drivers and impediments for participation in peer-to-peer rental. In System Sciences (HICSS), 49th Hawaii International Conference (pp. 4782-4791). IEEE. https://doi.org/10.1109/HICSS.2016.593

Kalamar, A. (2013, May 13). Sharewashing is the New Greenwashing. OpEdNews. http://www.opednews.com/articles/Sharewashing-isthe-New-Gr-by-Anthony-Kalamar-130513-834.html.

Kathan, W., Matzler, K., \& Veider, V. (2016). The sharing economy: Your business model's friend or foe? Business Horizons, 59(6), 663672. https://doi.org/10.1016/j.bushor.2016.06.006

Katz, V. (2015). Regulating the sharing economy. Berkeley Technology Law Journal, 30(4), 1067-1126.

Kenney, M., \& Zysman, J. (2016). The rise of the platform economy. Issues in Science and Technology, 32(3). https://issues.org/the-rise-ofthe-platform-economy

Kerrigan, H. (2018). Issue: The on-demand economy. SAGE Publishing, Inc. http://businessresearcher.sagepub.com/sbr-1946-105131-2873217/ 20180108/the-on-demand-economy 
DRUŠ. ISTRAŽ. ZAGREB GOD. 30 (2021), BR. 3, STR. 615-634

MAJETIĆ, F: CONCEPTUAL...
Kircherr, J., Reike, D., \& Hekkert, M. (2017). Conceptualizing the circular economy: An analysis of 114 definitions. Resources, Conservation and Recycling, 127, 221-232. https://doi.org/10.1016/j.resconrec.2017.09.005

Kovács, B., Morris, J., Polese, A., \& Imami, D. (2017). Looking at the 'sharing' economies concept through the prism of informality. Cambridge Journal of Regions, Economy and Society, 10(29), 335-348. https:// doi.org/10.1093/cjres/rsw046

Leoni, G., \& Parker, L. D. (2019). Governance and control of sharing economy platforms: Hosting on Airbnb. The British Accounting Review, 51(6), 100814. https://doi.org/10.1016/j.bar.2018.12.001

Lessig, L. (2008). Remix: Making art and commerce thrive in the hybrid economy. Penguin. https://doi.org/10.5040/9781849662505

Martin, C. J. (2016). The sharing economy: A pathway to sustainability or a nightmarish form of neoliberal capitalism? Ecological Economics, 121, 149-159. https://doi.org/10.1016/j.ecolecon.2015.11.027

Martin, M., Lazarevic, D., \& Gullström, C. (2019). Assessing the environmental potential of collaborative consumption: Peer-to-peer product sharing in Hammarby Sjöstad, Sweden. Sustainability, 11(1), 1-19. https://doi.org/10.3390/su11010190

Maslow, A. H. (1943). A theory of human motivation. Psychological Review, 50(4), 370-396. https://doi.org/10.1037/h0054346

Meelen, T., \& Frenken, K. (2015, January 14). Stop saying Uber is part of the sharing economy. Fast Company. https://www.fastcompany.com/ 3040863/stop-saying-uber-is-part-of-the-sharing-economy

Menor-Campos, A., Baños García-Moreno, M., López-Guzmán, T., \& Hidalgo-Fernández, A. (2019). Effects of collaborative economy: A reflection. Social Sciences, 8(5), 142. https://doi.org/10.3390/socsci8050142

Mordowanec, N. (2017, August 17). HomeExchange: A pioneer in the sharing economy. Reward Expert. https://www.rewardexpert.com/blog/ homeexchange-is-a-pioneer-for-collaboration

Muñoz, P., \& Cohen, B. (2017). Mapping out the sharing economy: A configurational approach to sharing business modeling. Technological Forecasting and Social Change, 125, 21-37. https://doi.org/10.1016/j. techfore.2017.03.035

Murillo, D., Buckland, H., \& Val, E. (2017). When the sharing economy becomes neoliberalism on steroids: Unravelling the controversies. Technological Forecasting \& Social Change, 125, 66-76. https://doi. org/10.1016/j.techfore.2017.05.024

Perren, R., \& Kozinets, R. V. (2018). Lateral exchange markets: How social platforms operate in a networked economy. Journal of Marketing, 82(1), 20-36. https://doi.org/10.1509/jm.14.0250

Porsch, L., Raubel, L., Juskevicius, R., Karanikolova, K., \& Naumanen, M. (2018). Study to monitor the business and regulatory environment affecting the collaborative economy in the EU. Final Report. Publications Office of the European Union.

Proserpio, D., Xu, W., \& Zervas, G. (2018). You get what you give: Theory and evidence of reciprocity in the sharing economy. Quan- 
DRUŠ. ISTRAŽ. ZAGREB GOD. 30 (2021), BR. 3, STR. 615-634

MAJETIĆ, F: CONCEPTÜAL... titative Marketing and Economics, 4(16), 371-407. https://doi.org/10. 1007/s11129-018-9201-9

Ranjbari, M., Morales-Alonso, G., \& Carrasco-Gallego, R. (2018). Conceptualizing the sharing economy through presenting a comprehensive framework. Sustainability, 10(7), 2336. https://doi.org/10.3390/ su10072336

Slee, T. (2015). What's yours is mine. against the sharing economy. OR Books. https://doi.org/10.2307/j.ctt1bkm65n

Schor, J. (2014, October). Debating the sharing economy. Great Transition. https://greattransition.org/publication/debating-the-sharing-economy

Schor, J. (2015, February 23). Getting sharing right. Contexts. https:// contexts.org/articles/on-the-sharing-economy/

Schor, J. (2017). Does the sharing economy increase inequality within the eighty percent?: Findings from a qualitative study of platform providers. Cambridge Journal of Regions, Economy and Society, 10(2), 263-279. https://doi.org/10.1093/cjres/rsw047

Schor, J. B., \& Attwood-Charles, W. (2017). The "sharing" economy: Labor, inequality, and social connection on for-profit platforms. Sociology Compass, 11(8), e12493. https://doi.org/10.1111/soc4.12493

Schor, J. B., \& Fitzmaurice, C. J. (2015). Collaborating and connecting: The emergence of the sharing economy. In L. A. Reisch \& J. Thøgersen (Eds.), Handbook of research on sustainable consumption (pp. 410-425). Edward Elgar Publishing. https://doi.org/10.4337/9781783471270.00039 Vaughan, R., \& Daverio, R. (2016). Assessing the size and presence of the collaborative economy in Europe. PwC UK.

Zervas, G., Proserpio, D., \& Byers, J. W. (2017). The rise of the sharing economy: Estimating the impact of Airbnb on the hotel industry. Journal of Marketing Research, 54(5), 687-705. https://doi.org/10.1509/ jmr.15.0204

\section{Konceptualni okvir za istraživanja ekonomije suradnje}

Filip MAJETIĆ

Institut društvenih znanosti Ivo Pilar, Zagreb, Hrvatska

Ovaj rad ima za cili uspostaviti sveobuhvatan i lako operacionalizirajući konceptualni okvir za istraživanja ekonomije suradnje. lako ova ekonomija privlači sve veću pozornost kompanija, potrošača, političara / regulatora i istraživača, široko prihvaćene konceptualizacije fenomena još uvijek nema. U ovom članku ekonomija suradnje obuhvaća profitnu i neprofitnu razmjenu proizvoda koji su: a) od vlasnika privremeno ustuplieni drugima na upotrebu (tj. dijeljeni) onda kada su podiskorišteni; b) koji su dijeljeni sporadično, tj. do određene miere; c) koji su dijeljeni od amatera / neprofesionalaca u slučajevima kada je 
DRUŠ. ISTRAŽ. ZAGREB GOD. 30 (2021), BR. 3, STR. 615-634

MAJETIĆ, F:

CONCEPTUAL... profesionalna dozvola za to dijeljenje potrebna; i d) koji su dijelieni putem online-platformi. Ako su svi ovi uvjeti (istodobno) ispunjeni, dijeljeni proizvodi obuhvaćaju dobra i usluge, a djelitelii mogu biti osobe (npr. P2P) i organizacije (npr. B2P). Predloženi konceptualni okvir raspravljen je u kontekstu ključnih koncepata "susjedskih" ekonomija suradnje - ekonomiji na zahtjev, ekonomiji honorarnih poslova, iz druge ruke i cirkularnoj ekonomiji te rentnoj ekonomiiji.

Ključne riječi: ekonomija suradnje, konceptualni okvir, istraživačko polje

\section{(c) (i) (8)}

Međunarodna licenca / International License:

Imenovanje-Nekomerciijalno / Attribution-NonCommercial 